Pure Sciences

Poster

Abstract ID: 126

\title{
Antibacterial property of crude extract from stem-bark and leaves of Rhizophora apiculata against selected bacterial fish pathogens
}

\author{
Jalal, K.C.A. ${ }^{a} \mid$ Zaima Azira ${ }^{b} \mid$ Kamaruzzaman, B.Y. ${ }^{a} \mid$ Akbar John, $B^{c} \mid$ Said Imaddudeen, $N^{b}$ \\ ${ }^{a}$ Department of Marine Science, Kulliyyah of Science, International Islamic University Malaysia \\ ${ }^{b}$ Department of Biotechnology, Kulliyyah of Science, International Islamic University Malaysia \\ 'INOCEM Research Station (IRS), Kulliyyah of Science, International Islamic University Malaysia
}

Introduction: Recently the wide range of commercial antibiotics in fish feed for aquaculture practices has led to antibacterial resistance, environmental pollution and residue build-up in fish tissue. Therefore new sources of antibiotics from natural sources need to be investigated to circumvent these problems. Rhizophora apiculata has been reported to have high antimicrobial activity due to the high concentration of tannin in the bark of the tree. Methods: Based on these contexts, this study was conducted to measure the antimicrobial activity of ethanol, ethyl acetate and distill water extracts from the stem-bark and the leaves of $R$. apiculata. 9 species of bacteria consist of $B$. subtilis, S. aureus, S. epidermidis, P.aeruginosa, P. mirabilis, H. alvei, V. alginolyticus, V. paraheamolyticus and $E$. coli were tested to measure their susceptibility to the extracts. The extracts were dissolved into 2 different concentrations which were $10 \mathrm{mg} / \mathrm{mL}$ and 50 $\mathrm{mg} / \mathrm{mL}$ or $10 \mathrm{ug} / \mathrm{disc}$ and $50 \mathrm{ug} /$ disc respectably, to determine the inhibitory effect of the extract upon the bacterial fish pathogen. Results: 2 species of Gram-positive bacteria which were $B$. subtilis and $S$. epidermidis have shown positive results with $9.0 \mathrm{~mm}$ to 16.0 $\mathrm{mm}$ of inhibition zone respectably while the other bacteria were resistant to the extract concentration administered. Conclusions: A continuous monitoring need to be carried out to comprehend the potential of Rhizophora apiculataas and other mangrove plants, which can be applied as an alternative source for environmental friendly antibacterial drug in pharmaceutical and aquaculture industries.

KEYWORDS: Rhizophora apiculata, anti-bacterial resistance, fish pathogen, disc diffusion method 